\title{
Sexually transmitted infections associated with vulvovaginal symptoms in adolescents denying sexual activity
}

\author{
Elizabeth Velarde-Jurado, MD, MSc, (1) Elizabeth Estrada-Reyes, MD, (1) Luis Eraña-Guerra, MD, (1) \\ A tlántida Raya-Rivera, MD, (1) E Yadira Velázquez-Armenta, BSc, M Sc, ${ }^{(1)}$ Alejandro A N ava-O campo, MD, MSc., ${ }^{(1,2)}$
}

\begin{abstract}
Velarde-Jurado E, Estrada-Reyes E, Eraña-Guerra L, Raya-Rivera A, Velázquez-Armenta EY, Nava-Ocampo AA. Sexually transmitted infections associated with vulvovaginal symptoms in adolescents denying sexual activity. Salud Publica Mex 2003;45 suppl 5:S641-S646. The English version of this paper is available too at: http://www.insp.mx/salud/index.html
\end{abstract}

\begin{abstract}
A bstract
Objective. To identify clinical, laboratory and ultrasonographic evidence of a probable sexually transmitted infection asso ciated with vulvovaginal symptoms in adolescents denying sexual activity. Material and MethodsThe medical records of female adolescents, aged $10-18$ years were reviewed.These women received first-time medical care for vulvovaginitis, between 1995 and 1999 at Hospital Infantil de México Federico Gómez, (Children's Hospital). Comparisons between groups were performed, as appropriate, by the unpaired Student's t-test, the Z test or the chi-square test; statistically significant differences were set at a twotailed $p<0.05$. 0 dds ratios with $95 \%$ confidence intervals were calculated. Results. Of 258 adolescents with vulvovaginitis, $53(20.5 \%)$ had a sexually transmitted microorganism and 52 of them denied ever having sexual activity. Age, education and socioeconomic level, development of sexual characters, and presence of menstruation did not differ between patients with and without sexually transmitted infections. The presence of sexually transmitted infections was associated with lower abdominal pain, abnormally colored vaginal discharge, a positive urine culture, and an abdominal ultrasonographic evidence, compatible with pelvic inflammato ry disease (ultrasono graphic odds ratio 144.8; $95 \%$ Cl 51.0 to 411.3). Conclusions. There is an association between sexually transmitted infections in young women with vulvovaginitis and lower abdominal pain,
\end{abstract}

\author{
Velarde-Jurado E, Estrada-Reyes E, Eraña-Guerra L, \\ Raya-Rivera A,Velázquez-Armenta EY, Nava-Ocampo AA. \\ Infecciones de transmisión sexual asociadas \\ a síntomas vulvovaginales \\ en adolescentes que niegan vida sexual activa. \\ Salud Publica Mex 2003;45 supl 5:S641-S646. \\ El texto completo en inglés de este artículo también \\ está disponible en: http://www.insp.mx/salud/index.html
}

\section{Resumen}

Objetivo. Identificar datos clínicos, de laboratorio y ultrasonográficos que permitan el diagnóstico de una infección de transmisión sexual asociada a síntomas vulvovaginales en las pacientes adolescentes que niegan vida sexual activa. Material y métodos. Se revisaron los expedientes de las adolescentes de 10 a 18 años de edad que requirieron atención médica de primera vez por vulvovaginitis entre 1995 y 1999 en el Hospital Infantil de México Federico Gómez. Las comparaciones entre grupos se llevaron a cabo con la prueba t de Student, la prueba de Z, o la de ji-cuadrada. Se utilizó un valor de $p<0.05$ para establecer diferencias estadísticamente significativas. Se calcularon razones de momios con intervalos de confianza de 95\%. Resultados De 258 adolescentes, en $53(20.5 \%)$ se identificó un microrganismo de transmisión sexual y 52 de ellas negaron tener vida sexual activa. No hubo diferencias estadísticas entre los dos grupos de ado lescentes en cuanto a la edad, los años de estudio, el nivel socioeconómico, la maduración sexual y la presencia de menarquia. El do lor abdominal en los cuadrantes inferiores, la coloración anormal de la secreción vaginal, un cultivo urinario positivo y un estudio ultrasonográfico abdominal compatible con enfermedad pélvica inflamatoria estuvieron asociados con infección de transmisión sexual. Con el estudio ultrasonográfico se obtuvo una razón de momios de 144.8 (intervalo de confianza $95 \% 51.0$ a 411.3). Conclusiones Se demostró una asociación entre infec-

(1) Hospital Infantil de México "Federico Gómez ", Secretaría de Salud. México, D F, México.

(2) Division of Clinical Pharmacology and Toxicology, Hospital for Sick Children.Toronto, Canada.

Received on: 0 ctober 31,2002 - Acepted on: June 16, 2003

Address reprint requests to: D r. Alejandro A N ava $\mathrm{O}$ campo. Division of Clinical Pharmacology and Toxicology, the Hospital for Sick Children, 555 U niversity Avenue.Toronto, 0 ntario M5G 1X 8, C anada. E-mail: navaocampo_aa@ yahoo.com 
abnormally colored vaginal discharge, a positive urine culture, and an abdominal ultrasonographic evidence compatible with pelvic inflammatory disease.The English version of this paper is available too at: http://www.insp.mx/salud/ index.html

Key words: bacterial vaginosis; differential diagnosis; pelvic inflammatory disease; sexually transmitted diseases; Mexico ción de transmisión sexual en adolescentes con vulvovaginitis y dolor abdominal bajo, secreción vaginal anormal, urocultivo positivo y un estudio ultrasonográfico compatible con enfermedad pélvica inflamatoria. El texto completo en inglés de este articulo también está disponible en: http:/ /www.insp.mx/salud/index.html

Palabras clave: diagnóstico diferencial; enfermedad pélvica inflamatoria; enfermedades de transmisión sexual; vaginosis bacteriana, México
A pproximately $20 \%$ of the population of almost 100 million in Mexico are adolescents; half of them are from 10 to 14 years of age and the remaining are between the age of 15 and 19 years. The male-to-female ratio is $1: 1 .^{1}$ As in several other countries, sexually transmitted infections (STI) represent a major public health problem among Mexican adolescents. For example, the rate of Trichomoniasis increased from 11.9 per 100000 in children aged 5 to 14 years to 178.3 per 100 000 in youths aged 15 to 24 years, which is higher than the rate in the general population. ${ }^{2}$ Furthermore, $8.5 \%$ of patients with STI seen at a Mexican National Institute of Health devoted to perinatal care were $<20$ years old, ${ }^{3}$ and a tertiary care Mexican hospital for sick children reported a rate of $18-25 \%$ of Chlamydia trachomatis infection among adolescents. ${ }^{4}$

As part of a tertiary-care medical center for sick children, the Department of Psychiatry and Adolescent Medicine of Hospital Infantil de México Federico Gómez, (Federico Gómez Children's Hospital, HIMFG) mainly attends patients referred from other services. Unfortunately, as previously discussed elsewhere, ${ }^{5}$ in Mexico we cannot legally guarantee privacy to our patients and therefore parents usually reject privacy for their daughters during clinical evaluations, resulting in a high rate of adolescents denying sexual activity, even in the presence of clinical and laboratory evidence of STI. Diagnosis is therefore delayed, and medical care and interaction with patients become complicated.

The present study was conducted to identify STI in female adolescents denying sexual activity, through analysis of demographic, biological, clinical, laboratory, and ultrasonographic (USG) characteristics of adolescents suffering vulvovaginitis.

\section{Material and Methods}

The Research Committee of the HIMFG approved the study. The medical records of patients aged between
10-18 years requiring first-time medical care at the Department of Psychiatry and Adolescent Medicine between January 1995 and December 1999, were reviewed. A diagnosis of infectious vulvovaginitis was the main inclusion criterion. Thirty-one of 304 patients were excluded for physiological leukorrhea, as well as 15 whose laboratory evidence of infectious vulvovaginitis was not available in the medical records. The rate of vulvovaginitis secondary to an STI was $20.5 \%$, i.e., 53 cases of a total of 258 adolescents included in the study. The medical records were reviewed by one pediatrician (EER), one specialist in adolescent medicine $(E V J)$, and one pediatric urologist (ARR), who were standardized to identify eligibility criteria and to retrieve information.

The following information was retrieved from the medical records of the 258 patients included in the study: age in years, level of education (elementary, middle, or higher), the socioeconomic level estimated by the Social Work Department of the HIMFG in either lower or medium strata, sexual maturation (grouped into Tanner stage I-II, Tanner III, and Tanner IV-V), menarche (present or absent), lower abdominal pain (present or absent), vulvar symptoms (present when there was an abnormal vaginal discharge, burning, and itching, or absent), urinalysis and urinary culture (positive or negative to bacterial growth), color of vaginal discharge (classified as either normal leukorrhea or abnormal discharge when a yellow or green vaginal discharge was present), odor of vaginal discharge (identified as either normal or abnormal depending on the presence or absence of fetid odor), and findings in abdominal USG defined as either negative or positive to STI when the presence of a pelvic inflammatory disease (PID) was established (e.g. free liquid $>1.5 \mathrm{ml}$ in the cul-desac, adnexitis, and tubo-ovarian abscess).

Patients were classified into two groups according to the vaginal microorganism identified. In the group of STI-associated with vulvovaginitis, adolescents with any of the following microorganisms were included. 
Chlamydia trachomatis was detected at the Laboratory of Virology of the HIMFG by direct immunofluorescence with monoclonal antibodies, or either by culture or Polymerase Chain Reaction (PCR) at the National Institute of Epidemiological Reference (INDRE) in Mexico City. At the Department of Pathology of the HIMFG the presence of Trichomonas vaginalis was determined by microscopic identification; Gardnerella vaginalis was identified by culture and by the presence of more than $20 \%$ clue cells in the smear; Neisseria gonorrhoeae by culture (Thayer-Martin). Human papillomavirus (HPV) testing was made using PCR on exfoliated vaginal cells. HPV was also diagnosed if visual identification of vulval, anal and vaginal condilomata was specified in the medical records. A nonSTI was considered if any microorganism not belonging to the STI group and currently considered as normal microbiological flora, e.g. lactobacilli-facultative grampositive bacteria, was identified. Finally, information on sexual activity and sexual abuse, were intentionally asked to any patient suffering vulvovaginitis.

For statistical analysis, comparisons between groups were performed, as appropriate, by the unpaired Student's t-test, the $\mathrm{z}$-test $(2 \times 2)$, or the chi-square test for comparisons between groups of a set of proportions. Statistically significant differences were considered if a two-tailed $p<0.05$, and when specified $95 \%$ confidence of intervals were computed by standard procedures. Finally, odds ratios were obtained by standard procedures for every demographic, clinical, laboratory and USG characteristic significantly different between STI and non-STI groups. ${ }^{6}$

\section{Results}

Of 258 adolescents, a sexually transmitted microorganism was identified in 53 (20.5\%) (Table I). Chlamydia trachomatis was the most common among five microorganisms. HPV was only identified in patients with sexual abuse. Microorganisms were present in similar groups of age.

Patients with STI were $14 \pm 2.5$ years old, $62.3 \%$ were in secondary school, $24.5 \%$ had a low socioeconomic level, $90.6 \%$ had presented menarche, and $49.1 \%$ had a Tanner IV-V, 43.4\% Tanner stage III, and 7.5\% Tanner stage I-II. Patients with non-STI were $13.4 \pm 2.8$ years old, $61.9 \%$ were in secondary school, $34.2 \%$ had a low socioeconomic level, and $44.4 \%$ had Tanner IVV, 40.5\% Tanner stage III, and $15.1 \%$ Tanner I-II. No statistically significant differences were detected between groups.

Patients with STI had higher rates of lower abdominal pain (34\% vs 15\%, 95\% CI for the difference 6 to
$26 \%$ ), abnormal color of vaginal discharge $(56.6 \%$ vs $39.5 \%, 95 \% \mathrm{CI}$ for the difference 1.2 to $21.5 \%$ ), positive urinary cultures $(9.4 \%$ vs. $2.0 \%, 95 \% \mathrm{CI}$ for the differences 3 to $69 \%$ ), and of an altered abdominal USG ( $41.5 \%$ vs. $0.5 \%, 95 \%$ CI for the difference 73 to $91 \%$ ) than patients with non-STI. All these differences were significant at $p<0.01$.

The STI and non-STI groups were not significantly different $(p>0.05)$ for rates of positive vulvar symptoms $(100 \%$ vs. $97 \%)$, abnormal odor of vaginal discharge ( $83 \%$ vs. $75.6 \%)$, urinary symptoms (30.1\% vs. $30.7 \%)$, and abnormal urinalysis (18.9\% vs. $15.1 \%$ ). According to the medical records, sexual abuse was declared by seven (11.7\%) adolescents with a STI, all of whom had HPV. In 45 (17.4\%) adolescents, a positive culture to Candida species was found concomitant to STI and non-STI. According to the odds ratio (Table II), a USG compatible with a pelvic inflammatory disease confers an elevated risk to have a STI associated with vulvovaginal symptoms. Finally, only one patient $(1.9 \%)$ with a STI versus $36(17.7 \%)$ with non-STI $(p<0.01 ; 95 \%$ CI for the difference -28.5 to -13.2 ) admitted to sexual activity.

Table I

Abnormal cervicovaginal microrganisms. Mexico City, 1995-1999

\begin{tabular}{|c|c|c|c|}
\hline Microorganism & $n=53(100 \%)$ & $\begin{array}{r}\text { Age } \\
\text { Mean } \pm\end{array}$ & $\begin{array}{l}\text { ars) } \\
\text { (ranges) }\end{array}$ \\
\hline Chlamydia trachomatis & $23(43.4)$ & $13.1 \pm 2.8$ & $(7-19)$ \\
\hline Trichomonas vaginalis & $11(20.8)$ & $14.7 \pm 2.3$ & $(11-18)$ \\
\hline Papillomavirus & $9 *(17.0)$ & $13.1 \pm 1.8$ & (11-17) \\
\hline Gardnerella vaginalis & $6(11.3)$ & $12.8 \pm 3.8$ & $(10-19)$ \\
\hline Neisseria gonorrhoeae & $4(7.5)$ & $13.8 \pm 2.5$ & $(11-17)$ \\
\hline
\end{tabular}

Table II

ReLEVANT CLINICAL AND LABORATORY INDICATORS of Sexually Transmitted Infections. MeXico City, 1995-1999

\begin{tabular}{lrc} 
Characteristic & Odds Ratio & $95 \% \mathrm{Cl}$ \\
A bnormal color of vaginal discharge & 2.0 & $1.1-3.7$ \\
\hline Lower abdominal pain & 2.9 & $1.5-5.6$ \\
\hline Positive urinary culture & 5.2 & $1.5-17.8$ \\
\hline Altered abdominal ultrasound & 144.8 & $51.0-411.3$
\end{tabular}




\section{Discussion}

According to the review article of Tobias and Ricer, each year three million teenagers acquire STI in the United States. ${ }^{7}$ Furthermore, about $50 \%$ of all HIV-infected individuals in the world are younger than 25 years. $^{8}$ Most of this infected population are women. Adolescents have the highest age-specific rates for a variety of STI with many biological and psychological factors favoring high-risk sexual activity. ${ }^{7}$ However, we did not identify any social or biological characteristic as a risk factor nor as a protective factor. This may be due to the homogeneity of the study population in relation to these factors.

In our study, Chlamydia trachomatis and Trichomonas vaginalis were present in almost $60 \%$ of cases with STI. The former is the most common sexually transmitted pathogen, ${ }^{9}$ and the latter has been found as the major microorganism identified among African women denying sexual activity. ${ }^{10}$ In relation with the three other microorganisms reported in our study, a $25 \%$ incidence for HPV in adolescents 15-19 years of age was recently reported in a Canadian study. ${ }^{11}$ It is commonly identified in sexually abused children, ${ }^{12}$ and long-term infection with some HPV strains increases the risk of cervical neoplasia. However, detection and long-term follow-up of infected patients remains a major epidemiological challenge. ${ }^{12-14}$ Gardnerella vaginalis has been isolated from $16 \%$ of Mexican adolescents with symptomatic vulvovaginitis. ${ }^{15}$ Interestingly, HPV and Gardnerella vaginalis, which used to be considered infections limited to women, can be present in the urogenital tract of men, ${ }^{16,17}$ complicating treatment and prevention of subsequent infections with these two microorganisms among female patients. Neisseria gonorrhoeae, the less common microorganism identified in the present stu$\mathrm{dy}$, is second only to chlamydial infections in the number of cases reported to the Centers for Disease Control and Prevention. ${ }^{18}$ Infection with either Chlamydia trachomatis or Neisseria gonorrhoeae can result in urethritis, cervicitis, pelvic inflammatory disease, and complications such as chronic pelvic pain, infertility and ectopic pregnancy. ${ }^{9,19}$

A limitation of the study was the diagnostic screening, performed in accordance with the criteria of the attending physician at the time the patient had the consultation. Whether a flaw in the diagnosis approach including clinical, laboratory, and USG examinations affects the direction of the study cannot be clarified in a retrospective design. Furthermore, different etiologies of STI were combined in the study. Therefore, symptoms and laboratory studies may not apply to all cases. For example, this study identified that lower abdominal pain was significantly different between patients with and without STI. However, in a crosssectional study design, Steinhandler et al found that abdominal pain was present in a similar proportion in patients with and without bacterial vaginosis. ${ }^{20}$ Also, we considered as part of the diagnostic tools the presence of a positive urinary culture which will certainly poorly contribute to evaluate patients with HPV for example, unless a concomitant bacterial infection is present.

Pelvic USG has proven to be a useful complementary tool in the diagnosis of PID in adolescents. ${ }^{21,22} \mathrm{In}$ our study, USG compatible with PID was present in $40 \%$ of adolescents with an STI. This high rate could be associated with the sonographers' awareness of the suspected diagnosis. However, this result can be explained by the fact that adolescents were denying sexual activity and therefore they waited until symptoms were completely present in practically all of them.

While honesty among scholar adolescents was identified in the United States, ${ }^{23}$ in our study almost all patients with STI denied sexual activity. In contrast with other countries where privacy rights have been the focus of an extensive analysis and are legally protected such as in the United States, ${ }^{24-26}$ in Mexico privacy protection of adolescents is not legally guaranteed, as we previously discussed elsewhere. ${ }^{5}$ Privacy has been an important cultural factor in determining the use of health care by Chinese and Vietnamese women. ${ }^{27}$ Sexual abuse might also contribute to an important rate of STI. In our study, we identified almost $15.3 \%$ of adolescents as having this problem. However, women younger than 20 years old constitute $50 \%$ of victims of sexual abuse in a Mexican specialized clinic devoted to this type of medical care, ${ }^{28}$ and since more than $50 \%$ of abuses were performed by a person related to the victim, disclosure of information in an unprotected environment is not expected.

We don't have enough programs available to inform or provide either anti-conception methods or safety sexual recommendations to adolescents attended at HIMFG. This deficiency is unfortunately not limited to our hospital and is reflected in other areas. For example, according to Population Action International, Mexico has a rate of 7 births for 100 women aged 15 to 19 years old. ${ }^{29}$ This rate is 17.5 times higher than in Japan, approximately 8.0 times than Spain and France, 2.9 times than United Kingdom, and 1.4 times than the United States of America. Since educational interventions have demonstrated to be successfully applied to low-income urban women and female college students to prevent unwanted pregnancy and human im- 
munodeficiency virus infections, ${ }^{30,31}$ we should attempt to implement educational efforts among adolescents and their families to protect them against sexually risky practices. In fact, more than $15 \%$ of patients with non-STI were able to report sexual activity. We could not determine whether this group of adolescents is probably more likely to take precautions to avoid STI. However, they could represent evidence that adolescents may take proper actions if they find where they can receive the proper support.

Women are more likely than men to have held a reproductive health discussion with a daughter, while no gender differences were observed for having had such a discussion with a son. ${ }^{32}$ These differences could also occur with our male colleagues, and therefore they may be inhibited to meet privately with female adolescents during their visits. Nurse participation in the primary management of adolescents potentially infected with a STI has also not been explored in our hospital. Nurses have developed an efficient program for survivors of sexual assault. ${ }^{33,34}$ It is likely that young women and their parents be more comfortable with a female health provider, regardless care is provided by a physician or a nurse, and this might help adolescents to disclose important information in relation with STI.

In conclusion, STI associated with vulvovaginal symptoms should be suspected in adolescents denying sexual activity, referring either a green or yellow vaginal discharge with lower abdominal pain, a positive urinary culture, and USG evidence of pelvic inflammatory disease. This approach deserves further study collecting similar data under a prospective research protocol in a greater number of patients. The confirmation of our findings may help to early detect patients with a STI. However, implementation of enough privacy to help the adolescents to disclose information on sexual activity and sexual abuse, together with a follow-up program to prevent long-term complications and subsequent infections, remain as two major challenges at the HIMFG.

\section{References}

1. Instituto N acional de Estadística, Geografía e Informática. Estados Unidos Mexicanos. XII Censo General de Población y Vivienda 2000: Resultados Finales. México, DF: IN EGI, 2002. Disponible en: http:// www.inegi.gob.mx/difusion/espanol/poblacion.

2. Instituto N acional de Estadística, Geografía e Informática. Estados Unidos Mexicanos. Incidencia de enfermedades por grupo de edad. México, DF: IN EGI, 1998.

3.Arredondo-García JL, N arcio-Reyes ML, C asanova-Román G, Figueroa-D amián R. Enfermedades transmitidas sexualmente (ETS) en un grupo de adolescentes que asisten a un instituto de atención perinatal. Gac Med Mex 1993;129:75-79.

4. Fernández-Paredes F, Sumano-A vendaño E, Escamilla-Avilés E, Hernández-Méndez JT. Infección genital por Chlamydia trachomatis en niñas y adolescentes. Bol Med Hosp Infant Mex 1986;43:595-598. 5.Velarde-Jurado E,Velázquez-Armenta Y, N ava-O campo AA. Mexican adolescents and sexually transmitted diseases:A privacy problem.J Adolesc Health 2002;31:4.

6. Daly LE, Bourke G]. Interpretation and uses of medical statistics. 0 sney Mead (UK): Blackwell Science Ltd, 2000.

7.Tobías BB, Ricer RE. Counseling adolescents about sexuality. Prim Care 1998:25:49-70.

8.W orld Bank. Investing in young lives:The role of reproductive health. W ashington, DC:W orld Bank, 1998. Disponible en: http:// www.worldbank.org/html/extdr/hnp/ population/ynglives/ynglives.htm. 9. US Preventive Services Task Force. Screening for chlamydial infection: Recommendations and rationale. Am J Prev Med 2001;20(3 Suppl 1): 90-94.

10. Buve A, W eiss HA, Laga M, van Dyck E, Musonda R, Zekeng $L$ et al. The epidemiology of trichomoniasis in women in four African cities. AID S 2001;15(Suppl 4):S89-S96.

11. Sellors JW, Karwalajtys TL, Kaczorowski J, Mahony JB, Lytwyn A, Chong $S$ et al. Incidence, clearance and predictors of human papillomavirus infection in women. CMAJ 2003;168:421-425. 12. Stevens-Simon C, N elligan D, Breese P, Jenny C, D ouglas JM Jr.The prevalence of genital human papillomavirus infections in abused and nonabused preadolescent girls. Pediatrics 2000;106:645-649. 13. Sherman ME, Lörincz AT, Scott DR,W acholder S, C astle PE, G lass AG et al. Baseline cytology, human papillomavirus testing, and risk for cervical neoplasia:A 10-year cohort analysis. J $\mathrm{N}$ atl $\mathrm{C}$ ancer Inst 2003;95:46-52.

14. Lazcano-Ponce E, Herrero R, Muñoz N , Cruz A, Shah KV,Alonso P et al. Epidemiology of HPV infection among Mexican women with normal cervical cytology. Int J C ancer 2001 91:412-420.

15. Linaldi-C amacho A, U rbina-G uerrero JR, C astañeda-N arváez JL. Vaginitis por Gardnerella vaginalis en niñas y adolescentes. Bol Med Hosp Infant Mex 1988;45:101-103.

16. Lazcano-Ponce E, Herrero R, Muñoz N , Hernández-Avila M, Salmerón J, Leyva A et al. High prevalence of human papillomavirus infection in Mexican males: Comparative study of penile-urethral swabs and urine samples. Sex Transm D is 2001;28:277-280.

17. Elsner $\mathrm{P}, \mathrm{H}$ artmann $\mathrm{AA}$, W ecker I. Gardnerella vaginalis is associated with other sexually transmittable microorganisms in the male urethra. Zentralbl Bakteriol Mikrobiol Hyg (A) 1988;269: 56-63.

18. Centers of Disease Control. Sexually transmitted disease surveillance 2001 supplement: Gonococcal Isolate Surveillance Project (GISP) annual report - 2001. A tlanta (GA): US D epartment of Health and Human Services, 2002. D isponible en: http://www.cdc.gov/std/ g2SP2001text8.fig.pdf.

19. W orld Health 0 rganization Task Force on the Prevention and Management of Infertility.Tubal infertility: Serologic relationship to past chlamydial and gonococcal infection. Sex Transm D is 1995;22:71-77. 20. Steinhandler L, Peipert JF, Heber W, Montagno A, Cruickshank C. Combination of bacterial vaginosis and leukorrhea as a predictor of cervical chlamydial or gonococcal infection. 0 bstet Gynecol 2002;99:603-607.

21. Golden N, Cohen H, Gennari G, N euhoff S. The use of pelvic ultrasonography in the evaluation of adolescents with pelvic inflammatory disease. Am J D is Child 1987;141:1235-1238.

22. Tepper R,Aviram R, Cohen N , C ohen I, Holtzinger M, Beyth Y. Doppler flow characteristics in patients with pelvic inflammatory disease: Responders versus nonresponders to therapy. J C lin Ultrasound 1998;26:247-249. 
23. Siegel D M,Aten MJ, Roghmann KJ. Self-reported honesty among middle and high school students responding to a sexual behavior questionnaire. J Adolesc Health 1998;23:20-28.

24. Chilton L, Berger JE, Melinkovich P, N elson R, Rappo PD, Stoddard J et al. American A cademy of Pediatrics, Pediatric Practice Action G roup and Task Force on Medical Informatics. Privacy protection and health information: Patient rights and pediatrician responsibilities. Pediatrics 1999;104:973-977.

25. Chesney RW. Privacy and its regulation:Too much too soon, or too little too late. Pediatrics 2001;107:1423-1424.

26. Gotlieb EM. Privacy rights, HIPAA, and the AAP:A bout right; about time. Pediatrics 2002;109:146-149.

27.Vu HH. Cultural barriers between obstetrician-gynecologists and Vietnamese/C hinese immigrant women. Tex Med 1996;92:47-52.

28. Martínez-Ayala H, Villanueva LA, Torres C, G arcía-Lara E. A gresión sexual en adolescentes. Estudio epidemiológico. Ginecol 0 bstet Mex 1999;67:449-453.

29. Population Action International. The PAI report card 2001: mundos diferentes, salud y riesgo sexuales y reproductivos. W ashington, DC: PAI,
2001. Disponible en: http://www.64.24.182.238/resources/publications/ worldofdifference/rr2_downloads.htm.

30. Saito MI. Sex education in school: Preventing unwanted pregnancy in adolescents. Int J Gynaecol 0 bst 1988;63(Suppl 1):S157-S160.

31. Carey MP, Braaten LS, Maisto SA, G leason JR, Forsyth AD, D urant LE et al. Using information, motivational enhancement, and skills training to reduce the risk of HIV infection for low-income urban women:A second randomized clinical trial. Health Psychol 2000;19:3-11.

32. Speizer IS, Mullen SA, A mégee K. Gender differences in adult perspectives on adolescent reproductive behaviors: Evidence from Lomé,Togo. Int Fam Plann Perspect 2001;27:178-185. Disponible en: http://www.guttmacher.org/pubs/journals/ 2717801.pdf.

33. Hutson LA. D evelopment of sexual assault nurse examiner programs. N urs C lin N orth Am 2002;37:79-88.

34. Stermac LE, Stirpe TS. Efficacy of a 2-year-old sexual assault nurse examiner program in a Canadian hospital. J Emerg N urs 2002;28:18-23. 